\title{
IT Governance Practices in Small and Medium-Sized Enterprises: Recommendations from an Empirical Study
}

\author{
Rui Huang ${ }^{1}$, Robert W. Zmud ${ }^{2}$, and R. Leon Price ${ }^{2}$ \\ ${ }^{1}$ School of Management \\ State University of New York at Binghamton \\ ${ }^{2}$ Michael F. Price College of Business \\ University of Oklahoma
}

\begin{abstract}
Much has been learned through IT governance research about the nature of IT-related decisions, the location of decision rights for these decisions, and governance mechanisms applied to facilitate associated decision processes in large organisations. Our knowledge about IT governance structures in small and medium-sized enterprises (SME), on the other hand, is quite limited. Adopting a qualitative and inductive approach, this study examines the nature and influence of IT governance in SMEs through interviews with executives from three SMEs. Our results demonstrate that IT decision authority was centralized in all three SMEs but that senior management involvement in governance procedures and communication practices about governance policies were observed to explain differences in these organisations' IT use. We propose recommendations based on the findings of this study.
\end{abstract}

\section{Introduction}

Organisations introduce IT governance mechanisms in order to rationalize and coordinate their IT-related decision making so that IT assets, efforts and investments are aligned with the organisation's strategic and tactical intents. Well-architected IT governance mechanisms involve careful consideration of a variety of issues: what are an organisation's critical IT decisions, what policies need to be put in place to guide these decisions, who should be accountable for and who should contribute to these decisions, what procedures should be followed in carrying out these decisions, and which type of coordination mechanisms are most appropriate given the natures of these decisions (Sambamurthy and Zmud 1999; Weill and Ross 2004).

Research on the nature and influence of IT governance mechanisms can be traced back to the 1960's (Brown 2005) with researchers examining a variety of fundamental issues including the definition of IT governance (Weill 2004), structural options for IT governance (Jenkins and Santos 1982; Zmud et al. 1986), and the drivers of IT governance structural forms (Brown and Magill 1998; Sambamurthy and Zmud 1999). Further, it is generally accepted that IT governance does matter. For example, consistent results have been observed regarding relationships between the centralization of IT 
governance and the patterns of IT use (e.g., Brown 1997): centralized IT governance tends to improve enterprise-wide efficiencies but suboptimizes in delivering value to local work units; and, decentralized IT governance tends to optimize in delivering value to local work units but yields enterprise-wide inefficiencies. Such enterprise-versus-local tensions is a recurrent theme of the IT governance literature (Weill and Ross 2004).

While most research on IT governance has been conducted within large enterprises, the organisational (i.e., institutional and managerial) structures of large enterprises tend to be quite distinct from those of small- and medium-sized enterprises (SMEs) (Meyer 1972). Along with other factors (e.g., technology and environment), organisational size (Starbuck 1965) and structural differentiation (Blau and Schoenherr 1971) induce considerable variation in organisational structures which in turn influence the nature of instituted decision structures (Ein-Dor and Segev 1982), including IT governance structures (Cross et al. 1997). In particular, SMEs tend to be characterized by centralized decision structures (Wilensky 1967), which engender centralized IT governance structures (Brown 1997; Sambamurthy and Zmud 1999).

Given the prior literature on IT governance and the likelihood of centralized IT governance, should it be expected that well-managed SMEs applying centralized IT governance structures would experience efficiencies in their use of IT but suboptimize in exploiting local work unit IT-related opportunities? Or, would the relatively smaller size of SMEs diminish enterprise-local tensions and enable both efficiencies and local effectiveness to be observed? In the absence of empirical evidence in the SME context, it is difficult to say.

The research question of this study therefore is: how can SMEs optimize IT performance through governance practices? In the following sections, we provide overviews of what is currently known about the SME context (i.e., SME organisational structures, IT endowments, and IT management posture) and about IT steering committees, a key IT governance mechanism. We next describe three case studies, and then use observations drawn from within and across case analyses to propose recommendations for optimizing IT performance in SMEs.

\section{The Small- and Medium-Sized Enterprise (SME) Context}

SMEs constitute the great majority of all organisations and represent a vibrant economic engine with significant potential to drive economic and employment growth as well as poverty alleviation ${ }^{1}$. Generally, the term SME applies to firms employing fewer than 500 workers (Levy and Powell 2005). Given their size and market reach, SMEs generally hold small market shares and tend to manoeuvre in operating regimes much more characteristic of classic perfect competition, relative to their larger counterparts, as they are less able to influence market prices through strategic actions (Storey and Sykes 1996). On the other hand, their smaller size enables SMEs to be nimbler (flexible, innovative, etc.) in responding to customer and market demands (Hay and Kamshad 1994). The remainder of this section synthesizes extant research in characterizing SMEs with regard to their organisational structures, their IT endowments and their IT management postures.

\footnotetext{
1 "World Bank Review of Small Business". IFC, World Bank, MIGA. 2001.
} 


\subsection{SME Organisational Structures}

Complexity, formalization and centralization are three commonly examined attributes of organisational structure (Hall 1972; Pugh et al. 1968). Complexity refers to the number of hierarchical levels, the number of departments or functions, and the extent of specialization (Blau and Schoenherr 1971). Formalization defines the degree to which rules and procedures are specified, promoted and adhered to (Hall 1972). Centralization reflects the extent to which the locus of formal control is held by a central decisionmaking authority (Child 1972).

Regarding their organisational structures, SMEs tend to exhibit low levels of formalization and complexity when compared to large firms (Ghobadian and Gallear 1996; Storey 1994). Along with flatter organisational structures and simpler organisational processes, SMEs tend to exhibit rich information networks (employees at all levels are likely to interact with one another on a regular basis) and a high degree of internal transparency (employees at all levels are likely to be cognizant of others' work assignments and roles, perspectives and taken decisions) thus allowing coordination in the absence for formalized rules and procedures (Street and Meister 2004). The SME owner/CEO has considerably more personal influence over a firm's strategies, tactics and operations than her peers in larger enterprises as well as considerable personal opportunity to engage in decision processes across the firm (Levy and Powell 2005). As a result, although a flat, informal organisational structure is likely to exist, decision making tends to be quite centralized around the owner/CEO (Bianchi 2002).

\subsection{IT Endowments}

Relative to larger enterprises, SMEs tend to be constrained regarding their endowments of financial resources and IT capabilities, prompting many SMEs to make extensive use of packaged solutions, third party service providers and external consultants (Keasey and Watson 1993). Not surprisingly, Thong (2001) has observed that SMEs spend proportionally less on IT than larger businesses. Three primary explanations validate this reality. First, SMEs' very influential owner/founders tend to have limited prior IT expertise and experience, unless the business itself is IT-enabled or IT-based (Hadjimanoulis 2000). Not unexpected, the expertise of SME owners/founders typically lays in one or more non-IT aspects of the business, e.g., the product or service offered, external constituencies (customers, suppliers, regulators, etc.), operational processes, etc. In the absence of strong understanding of IT issues, owners/founders decision styles regarding IT tend to be reactive (Bianchi 2002) and, when exercised, tend to be operational rather than strategic and tactical (Lybaert 1998). Second, SMEs' employees tend to be generalists, rather than specialists, hired for their business skills, not necessarily their technology skills. The IT knowledge held by these employees is often quite limited, as their attention is most often directed toward ensuring core business survival rather than driving IT innovation regarding products, services or processes (Levy and Powell 2005). As a result, employees of SMEs generally hold low awareness of the potential benefits and costs of IT (Thong 1999). Third, given available resources as well as the nature of the IT work carried out, it is often 
difficult, and generally unnecessary, for SMEs to attract and retain highly capable IT professionals.

\subsection{IT Management Posture}

Because of the limited IT perspectives of owners/founders and a lack of IT proficiency across these firms' employees, most SMEs maintain quite small internal IT groups that tend to look outside the firm for identifying, acquiring, developing, installing and supporting IT-enabled business solutions (Thong 2001). Invariably, the decision orientation of this internal IT group tends to be focused on the short-term (e.g., little time spent on IT planning, repairing rather than upgrading existing systems) and on operational efficiency (Hagmann and McCahon 1993; Levy and Powell 2005). Further, the work processes and decision processes associated with this internal IT group tend to be less mature, lacking both rigor and consistency (Thong 1999), compared to those of IT groups in larger organisations. As a result, the introduction of new IT-enabled business solutions often occurs in a fragmented manner without systematic strategic foresight (Foong 1999).

\subsection{Summary}

SMEs are associated with a number of characteristics that distinguish them from larger organisations, particularly with regard to their organisational structures, IT endowments, and IT management postures. The decision structures of SMEs tend to be centralized, flat and informal. Financial constraints limit their abilities to invest in IT and to attract highly capable IT professionals. Finally, the internal IT groups of SMEs often lack process maturity and a long-term focus.

\section{IT Steering Committees}

IT steering committees represent a governance mechanism frequently applied to ensure the alignment of IT investments with business priorities and to otherwise provide oversight of organisations' IT-related activities. As typically established, the IT steering committee is a formally recognized group of senior executives representing differing perspectives that meets on a regular basis (McKeen and Guimaraes 1985 , p. 1344). IT steering committees function as a "board of directors" and act as a liaison device among various functional groups by facilitating inter-unit coordination, setting IT policies, allocating resources, and monitoring progress of IT projects (Torkzadeh and Xia 1992). Without steering committees, "individual managers are left to resolve isolated issues as they arise, and those individual actions can often be at odds with each other" (Weill and Ross 2005, p. 26).

Firms using IT steering committees have been found to exhibit greater executive attention to IT-related activities (Vadapalli and Mone 2000), a greater commitment to planning practices (Doll and Torkzadeh 1987), and a forward-looking IT project portfolio (McKeen and Guimaraes 1985). In addition, steering committees set the tone of business-IT relationships at an enterprise level (Ross et al. 1996) as business executives interact with the CIO in deliberating on IT-related issues and initiatives. 
The design (i.e., who participates) and focus of IT steering committees varies considerably. The CIO typically plays a proactive role (Earl and Feeny 1994). Besides the CIO, participants might involve senior executives, other IT executives and representatives from functional areas, business units and/or process leaders. Steering committees largely comprised of executive-level participants tend to emphasize standardization and efficiency as well as better leveraging of IT to improve profitability; steering committees largely comprised of participants representing operating areas tend to focus on improving operating performance; and steering committees largely comprised of senior managers representing business operating area and IT operating areas tend to focus on achieving optimal asset utilization (Weill and Ross 2005).

To summarize, IT steering committees provide overview of IT-related activities. They serve as a channel for business and IT executives to collaboratively initiate, plan, and manage IT projects. The design of IT steering committees differentiates an organisation's focus on IT issues at either enterprise-level or operational-level.

\section{Research Design}

To examine IT governance practices in SMEs and the impacts of these governance practices on the success achieved by SMEs in their IT use, a qualitative analysis of three case sites was undertaken (Yin 1984). By using the interview as the primary collection device, the cues used are framed within the interviewee's specific context (Kaplan and Maxwell 1994), and data could be collected from interviewees (i.e., senior managers in SMEs) whose organisational roles were most appropriate given the questions being asked.

The three SMEs selected - two for-profit SMEs (a manufacturing firm and a health services firm) and a non-profit SME - achieved a sampling strategy aimed at realizing variation in organisational objectives, strategies, structures and processes so as to reduce contextual biases (Dubé and Paré 2003; Rumelt 1991). Pharma is a manufacture subsidiary of an international pharmaceutical company, with businesses in Asia Pacific, North America, and Europe. HealthCare is a health care management organisation with multiple offices in three U.S. States that provides patient care services to their physician partners. Agriculture is a non-profit research foundation that engages in applied research as well as provides consultation services in agriculture techniques and advanced plant science. Demographic data along with interviewees from the field sites are provided in Table 1.

Table 1. Demographic Information on Research Sites

\begin{tabular}{|l|l|l|l|}
\hline & HealthCare & Agriculture & Pharma \\
\hline Firm Size & 182 & 300 & 360 \\
\hline IT Group Size & 12 & 14 & 10 \\
\hline Interviewees & CIO & CIO & CIO \\
& 4 Divisional VPs & 2 Divisional & $\begin{array}{l}\text { Controller, Divisional } \\
\text { VP }\end{array}$ \\
\hline
\end{tabular}


Entry to a organisation occurred through the CIO. After this initial interview, other interviewees were identified based on snowball sampling, in which the CIO was asked for suggestions of the appropriate senior managers of operational or staff units with the greatest potential to obtain value from IT use. All interviewees were asked questions about their understanding of the organisation's business tactics and strategies, IT governance structure, and IT use ${ }^{2}$. Each interview lasted between 30 and 50 minutes.

\subsection{A Priori Specification of Constructs}

Following Bourgeois and Eisenhardt (1988), we identified four potentially important constructs from the literature: decision loci, senior management involvement in IT governance processes, IT governance communication practices, and IT success. A priori specification of constructs helps shape the initial research design and analysis, and permits researchers to measure constructs more accurately (Eisenhardt 1989). We now provide a brief description of each of these constructs.

\section{Decision Loci.}

Previous studies in IT governance indicate that three governance structures are most prevalent: centralized, decentralized, and hybrid structures. Specifically, with centralized governance structures, IT decisions are made from a top-down, enterprisewide perspective. With decentralized governance structures, IT decisions are made from a bottom-up, localized (e.g., business unit, functional department, etc.) perspective. Hybrid structures (a.k.a. the federal governance mode) finds IT decisions being made collaboratively by representatives holding enterprise-wide and local perspectives. The primary advantage of centralized structures are the operational efficiencies and enterprise-wide synergies that result, whereas the major advantage of

Table 2. Centralized and Decentralized Governance Structures

\begin{tabular}{|c|c|c|}
\hline Decision Structure & Advantages & Disadvantages \\
\hline Centralization & $\begin{array}{l}\text { - Enterprise-wide infrastructure } \\
\text { - Economies of scale and scope } \\
\text { - Cost control } \\
\text { - Enterprise-wide project } \\
\text { prioritization } \\
\text { - Elimination of redundant } \\
\text { functions }\end{array}$ & $\begin{array}{l}\text { - Loss of local autonomy } \\
\text { - Overlooking local needs } \\
\text { - Bureaucracy } \\
\text { - Slow response times }\end{array}$ \\
\hline Decentralization & $\begin{array}{l}\text { - Locally-customized business } \\
\text { solutions } \\
\text { - Fast, flexible responses to } \\
\text { customers } \\
\text { - Fast, flexible responses to } \\
\text { competition }\end{array}$ & $\begin{array}{l}\text { - Duplication of business } \\
\text { solutions and IT services } \\
\text { - Higher operational costs } \\
\text { - Loss of a single-enterprise } \\
\text { view }\end{array}$ \\
\hline
\end{tabular}

\footnotetext{
${ }^{2}$ Interview protocol is available upon requests.
} 
decentralized structures is the local control enabling flexibility in responding to customer needs and competitive requirements (Brown 1997). A federal governance mode potentially provides for the advantages of both centralized and decentralized structures by centralizing certain IT decisions and decentralizing others (Zmud et al. 1986). Studies have sought to understand why organisations adopt specific IT governance structures (e.g., Sambamurthy and Zmud 1999) and under what conditions do firms choose to implement a hybrid IT governance solution (Brown 1997). Researchers have concluded that organisational choices of IT governance structures depend on numerous factors, including organisational structure, business strategy, industry, and firm size (Brown 2005; Sambamurthy and Zmud 1999; Weill and Ross 2004). Table 2 summarizes the advantages/disadvantages of centralized and decentralized governance structures.

\section{Senior Management Involvement in IT Governance Processes}

To ensure the alignment between business and IT and provide a high-level overview of IT practices, senior management is often involved in IT governance processes (Weill and Ross 2005). Senior management involvement refers to personal interventions and participation of executive managers in the decision-making processes of IT-related issues. The involvement of executives in IT decisions occurs through formal and informal pathways. Formally, senior management gets involved in IT decisions through governance bodies - such as steering committees - that shape strategies and policies (Doll 1985). Informally, senior IT decision makers interact with executive-level and senior operating managers to derive strategic IT directions and to deliberate on alternative solutions for critical business and IT issues.

\section{IT Governance Communication Practices}

In order for an organisation's members to behave appropriately as they engage with others when contributing to IT-related actions, it is beneficial that a mutuallyunderstood view of what represents enterprise-appropriate IT actions is held by these interacting members (Lind and Zmud 1995). For such a common understanding to emerge, it is desirable that enterprise policies, guidelines, and practices regarding appropriate and deviant IT-related behaviors be disseminated (Uzzi 1996; Walker et al. 1997). IT governance policies, guidelines and practices can be communicated through a variety of communication channels, each of which is characterized by distinctive capabilities (Carlson and Zmud 1999; Daft and Lengel 1986). The identification of these communication channels will help us categorize the impacts of communication practices on IT performance.

\section{IT Success}

Applying the lens of Porter's value chain (Porter 1985), IT has the potential to enable or support most organisational core work and managerial processes. Strategically, organisations can apply IT to enhance business flexibility, reduce operation costs, innovate new products or processes, create and penetrate new markets, and provide value-added services to stakeholders (Sambamurthy et al. 2003). Tactically and operationally, organisations can apply IT across the value chain activities to improve work process efficiency and effectiveness internally and, increasingly, also externally (Krishnan et al. 2007). 
Table 3. Variable Operationalization

\begin{tabular}{|c|c|c|}
\hline Construct & Sub-Category & Description \\
\hline \multirow[t]{3}{*}{ Decision Loci } & Centralization & $\begin{array}{l}\text { Decisions made by corporate-level } \\
\text { IT/business senior managers }\end{array}$ \\
\hline & Hybrid & $\begin{array}{l}\text { Decisions jointly made by } \\
\text { corporate and divisional senior } \\
\text { managers }\end{array}$ \\
\hline & Decentralization & $\begin{array}{l}\text { Decisions made by divisional } \\
\text { senior managers }\end{array}$ \\
\hline \multirow{2}{*}{$\begin{array}{l}\text { Senior Management } \\
\text { Involvement in IT } \\
\text { Governance } \\
\text { Processes }\end{array}$} & Formal Involvement & $\begin{array}{l}\text { Active participation of executive } \\
\text { managers in formal IT steering } \\
\text { committees }\end{array}$ \\
\hline & Informal Involvement & $\begin{array}{l}\text { Senior managers, categorized as } \\
\text { corporate senior managers, } \\
\text { divisional senior managers or } \\
\text { both, having regular interactions } \\
\text { with the CIO }\end{array}$ \\
\hline \multirow[t]{2}{*}{$\begin{array}{l}\text { IT Governance } \\
\text { Communication } \\
\text { Practices }\end{array}$} & Number of Channels & $\begin{array}{l}\text { Number (and types) of } \\
\text { communication channels used to } \\
\text { communicate IT governance } \\
\text { policies, guidelines and practices } \\
\text { throughout the SME. }\end{array}$ \\
\hline & $\begin{array}{l}\text { Primary } \\
\text { Communication } \\
\text { Channel }\end{array}$ & $\begin{array}{l}\text { The primary communication } \\
\text { channel used to communicate IT } \\
\text { policies, guidelines and procedures } \\
\text { throughout the SME. }\end{array}$ \\
\hline \multirow[t]{3}{*}{ IT Success } & Efficiency of IT Use & $\begin{array}{l}\text { How efficient the firm has been in } \\
\text { its use of IT (a 5-point scale with } \\
5 \text { representing the highest } \\
\text { efficiency; averaged by number of } \\
\text { respondents). }\end{array}$ \\
\hline & $\begin{array}{l}\text { Breadth of current IT } \\
\text { use }\end{array}$ & $\begin{array}{l}\text { The number of distinct areas } \\
\text { identified, aggregated across } \\
\text { interviewees, where IT is being } \\
\text { appropriately used }\end{array}$ \\
\hline & $\begin{array}{l}\text { Breadth of potential } \\
\text { IT use }\end{array}$ & $\begin{array}{l}\text { The number of distinct work } \\
\text { processes identified, by any } \\
\text { interviewees, as being actively } \\
\text { considered or planned for future } \\
\text { IT use. }\end{array}$ \\
\hline
\end{tabular}

There are several ways of assessing organisational success in IT use. Following Edmondson, Winslow, Bohmer, and Pisano (2003), we consider efficiency and breadth of IT use. Efficiency of IT use primarily refers to the extent to which cost and productivity advantages accrue in the deployment of IT assets and capabilities. 
Breadth of IT use reflects the extent to which IT assets and capabilities are used in supporting work processes across the organisation (Sambamurthy and Zmud 1992). Underlying the breadth in use are two distinct constructs: breadth in current IT use, and breadth in potential IT use. Here, the former breadth aspect reflects work processes currently being enabled/supported by IT while the latter reflects the recognition of work processes that, though not currently, should be enabled/supported by IT.

\subsection{Data Sources}

Transcriptions of the interviews were coded by three individuals (the author and two research assistants knowledgeable about IT but not otherwise involved in the study) using a coding scheme developed based on the priori specification of constructs ${ }^{3}$. The coding scheme captures the location of IT decisions, how senior management was involved in IT decision-making, the channels used to communicate IT policies, guidelines and procedures, and organisational success in IT use. Independent coding was first conducted, and the initial inter-rater reliability was $79 \%$. Coding differences were then identified and reconciled through discussions among the three coders.

Interview comments from the CIOs were used to capture governance practices in each organisation as the CIOs were the informants possessing the most comprehensive understanding of their organisations' IT governance structures and processes, senior management involvement in IT-related decision processes, and the organisations' communication practices regarding IT governance policies, guidelines and procedures. Interview comments from the senior operating/functional managers were used to capture IT performance as these individuals possessed (collectively) the most realistic, unbiased views regarding the efficiency of IT use, where IT is currently deployed, and where IT should be (though not currently) deployed. To achieve a consistency in the cross-site analysis, analytic attention was limited to the "investment and prioritization" IT decision domain, the only IT decision domain for which all three organisations had established IT governance processes. Table 3 presents the operationalization of each construct.

\section{Data Analysis}

The search for patterns in the data was assisted by 1) understanding of the governance practices and IT success within each firm, and 2) comparing the differences in governance practices and IT success across three firms. Table 4 presents the primary coding results. Our discussion of data patterns draws from both the coding result and interview comments.

\subsection{IT Success}

The three organisations as a group performed best in terms of the efficiency in IT use, then current breadth in IT use and lastly potential breadth in IT use. Nevertheless, we observed differences in the nature of these organisations' success in deploying IT.

\footnotetext{
${ }^{3}$ The authors can provide coding rules upon requests.
} 
Table 4. Coding Results

\begin{tabular}{|l|l|l|l|}
\hline & HealthCare & Agriculture & Pharma \\
\hline Decision Loci & $\begin{array}{l}\text { Centralized } \\
\text { Corporate } \\
\text { Executives } \\
\text { CIO }\end{array}$ & $\begin{array}{l}\text { Centralized } \\
\text { CIO }\end{array}$ & $\begin{array}{l}\text { Centralized } \\
\text { CIO }\end{array}$ \\
\hline $\begin{array}{l}\text { Senior Mgt } \\
\text { Involvement: Formal } \\
\text { Involvement }\end{array}$ & $\begin{array}{l}\text { Corporate } \\
\text { Executives } \\
\text { CIO }\end{array}$ & $\begin{array}{l}\text { No use of formal } \\
\text { steering committees }\end{array}$ & $\begin{array}{l}\text { CIO } \\
\text { Divisional } \\
\text { Executives }\end{array}$ \\
\hline $\begin{array}{l}\text { Senior Mgt } \\
\text { Involvement: Informal } \\
\text { Involvement }\end{array}$ & $\begin{array}{l}\text { Corporate } \\
\text { Executives }\end{array}$ & $\begin{array}{l}\text { Divisional } \\
\text { Executives }\end{array}$ & $\begin{array}{l}\text { Divisional } \\
\text { Executives }\end{array}$ \\
\hline $\begin{array}{l}\text { Number of } \\
\text { Communication } \\
\text { Channels }\end{array}$ & $\begin{array}{l}\text { Email } \\
\text { Word of Mouth }\end{array}$ & $\begin{array}{l}\text { Paper Document } \\
\text { Formal Meeting } \\
\text { Word of Mouth }\end{array}$ & $\begin{array}{l}\text { Intranet } \\
\text { Paper } \\
\text { Document } \\
\text { Formal Meeting } \\
\text { Word of Mouth }\end{array}$ \\
\hline $\begin{array}{l}\text { Primary } \\
\text { Communication } \\
\text { Channel }\end{array}$ & Email & Paper Document & Intranet \\
\hline Efficiency of IT Use & $\begin{array}{l}3.2 \\
\text { (moderate) }\end{array}$ & $\begin{array}{l}3.3 \\
\text { (moderate) }\end{array}$ & $\begin{array}{l}4.3 \\
\text { (high) }\end{array}$ \\
\hline $\begin{array}{l}\text { Breadth of current IT } \\
\text { Use }\end{array}$ & $\begin{array}{l}3 \\
\text { (moderate) }\end{array}$ & $\begin{array}{l}2 \\
\text { (limited) }\end{array}$ & $\begin{array}{l}5 \\
\text { (high) }\end{array}$ \\
\hline $\begin{array}{l}\text { Breadth of potential } \\
\text { IT Use }\end{array}$ & $\begin{array}{l}1 \\
\text { (moderate) }\end{array}$ & $\begin{array}{l}1 \\
\text { (limited) }\end{array}$ \\
\hline
\end{tabular}

Pharma performed best regarding both the efficiency of IT use and the breadth of current IT use, but was limited in its breadth of potential IT use. Healthcare performed moderately well in all three performance categories and was observed to be the best in the breadth of potential IT use. Agriculture was observed to have limited performance in both current and potential breadth of IT use but moderately well in efficiency in IT use.

\subsection{IT Governance Structure}

We observed from the data that each of the organisations applied a centralized IT governance structure. The comments given below illustrate that, in general, key IT decisions were the responsibility of the CIO alone at Agriculture and Pharma, and by the $\mathrm{CxOs}$ (including the $\mathrm{CIO}$ ) at HealthCare. 
Now as those things (building an infrastructure) have been put in place, and hopefully become reliable and functional, we've tried to turn towards what tools we need from a business perspective, and from an operational perspective. Those decisions in terms of what we need are ultimately mine. (CIO, Agriculture)

Work prioritization is a daily decision but is critical to customer service. We have global standards for many things, like Microsoft BackOffice, things like that. But there are many decisions that are made on how you are going to sit on infrastructure, what tools you are going to use, how tight do you need to be on security, where are you going to focus your energies, and how do you manage your money. For this site, it (the decision right) will be here (with me). (CIO, Pharma)

The IT steering committee is made up of the CEO, the COO, the CFO, and the CIO. We collectively make those decisions. (CIO, HealthCare)

\subsection{Senior Management Involvement in IT Governance Processes}

Interviewees indicated the involvement of senior management as either formal via IT governance bodies such as steering committees or informally via personal relationships driven by the CIO. More specifically, formal senior management involvement was observed at HealthCare and Pharma, whereas informal senior management involvement was observed at Agriculture.

Formal IT steering committees enable participating senior management to meet regularly to discuss, debate and contribute to IT decisions, thus providing a formal, recurring vehicle through which the CIO interacts with other senior managers. The IT steering committee at HealthCare consisted of the $\mathrm{CxO}$ officers including the CIO. Divisional/operating senior managers had limited, if any, direct involvement in ITrelated decision processes:

We have a formal IT steering committee. The IT steering committee is made up of the $\mathrm{CEO}$, the $\mathrm{COO}$, the $\mathrm{CFO}$, and the $\mathrm{CIO}$. We collectively make IT decisions. (CIO, HealthCare)

An IT steering committee also existed at Pharma. Although decision rights were ultimately with the CIO, divisional/operational senior managers were directly engaged in IT decision processes through this committee. Unlike HealthCare, however, corporate senior managers had limited direct involvement in IT-related decision processes:

We do have a committee that when people look at different systems and prioritize overall IT resources, we have a committee made up of different functional areas. We do have limited resources, and everybody's priority is number one. But you only have so many resources. So we have a committee for that. The committee has somebody from manufacturing, quality, maintenance, IT, and accounting. The nature of that group is to 
look at the various demands on IT. IT creates this committee so that everybody would know what's going on, and everybody has input to what projects will be worked on, where we are going to spend our resources. (CIO, Pharma)

Not all SMEs, however, implement formal steering committees for IT decision making. Nevertheless, the CIO still needs to connect with business managers to ensure the alignment between business and IT (Reich and Benbasat 2000). Such connections are established through informal interactions amongst the $\mathrm{CIO}$ and other senior executives. At Agriculture, no formal IT steering committee existed; rather, the $\mathrm{CIO}$ interacted informally with operational/functional executives to gain their input into key IT decisions:

Those decisions in terms of what we need are ultimately mine. But they are certainly made based on interaction and collaboration with the division directors of the three divisions. So I'll meet with those guys, we'll in a very informal manner talk about their needs, their coming needs. (CIO, Agriculture)

\subsection{IT Governance Communication Practices}

As the organisational structures of SMEs tend to be flat and lacks standardization and formally-defined work processes, rich information networks amongst members serve as a primary vehicle for work direction and coordination (Ghobadian and Gallear 1996). Consistent with such an orientation, we found informal, interpersonal channels (e.g. word of mouth) being used in all three organisations to communicate IT governance policies and procedures. Still, we did find differences across the three case sites with regard to the communication of their IT governance policies, guidelines and practices.

Pharma indicated the use of four communication channels, i.e., an Intranet site, paper documents, formal meetings, and word of mouth:

The general policies, which are really a few formal policies of IT, there are some in the employee handbook that all employees are assigned, which is the Internet for appropriate use, your email can be reviewed, all the fundamental information confidential, all that is in the employee handbooks that every employee has been assigned. Other policies as we write them, will be published on the company Intranet... When a new employee comes in, there is employee orientation and the handbook. Typically when someone comes in, someone from IT spends a few minutes with them, how you do your mail, here's this, here's that. And then they are informed where these things are. (CIO, Pharma)

In contrast, HealthCare only used two channels (email and word of mouth), while Agriculture used three channels (document, formal meeting, word of mouth).

The communication of IT policies and procedures is informal, maybe just via email or word of mouth. We don't have a documented IT steering 
committee, the policies and procedures that the whole company knows about. It's just informal with senior management. (CIO, HealthCare)

We use standardized form, standard language, standard layout for presenting the information, what projects were approved, what projects were not approved, and why they weren't approved... Employees get oriented to the firm, and its general business practices. When they bring a software request forward, they'll find out from their peers, their division director that's something we do on a quarterly basis, and that's the process. (CIO, Agriculture)

\section{Recommendations for SME Governance Practices}

Consistent with the results of prior research on IT governance (Brown 2005; Sambamurthy and Zmud 1999; Weill and Ross 2004) with the earlier reported research stating relatively low levels of IT process maturity as well as low levels of IT capabilities across SME employees, the patterns we observed across the three case studies allowed us to draw inferences that centralized IT decision structures would be most prevalent within SMEs. In addition, given that centralized structures enable an enterprise-wide perspective that lead to efficient allocation of IT and business resources (Brown 1997), we further suggest that SMEs tend to focus on operational efficiency when they implement a centralized decision structure.

Despite the commonality of centralized IT decision structures, the success achieved by SMEs in their IT deployments was observed to vary. We drew general inferences that differential effects from IT use across the three cases were induced by variations observed in these firms regarding senior management involvement in their IT governance processes as well as their IT governance communication practices. Based on these inferences, we give recommendations for IT governance practices in SMEs.

\subsection{Senior Management Involvement in IT Governance Processes}

Referring back to Table 4, it can be observed that Pharma and Healthcare had implemented formal IT steering committees while Agriculture had not. In addition, Pharma and Healthcare generally outperformed Agriculture (though Agriculture and Healthcare were essentially comparable regarding efficiency in IT use). The picture that emerges from our data indicates the performance advantages of establishing a formal IT steering committee within SMEs. A network perspective can be used in understanding the influence of IT governance structures with successful IT use (Granovetter 1985).

Rooted in Granovetter's original conceptualization of embeddedness is the distinction between structural and relational embeddedness (Granovetter 1992). Structural embeddedness stresses the structural position in the network, whereas relational embeddedness emphasizes the characteristics of the relationships within the network (Gulati 1998). Both types of embeddedness are associated with the organisational governance mechanisms in that structural embeddedness is involved 
with the fashioning of norms and practices at institutional level, while relational embeddedness facilitates the building of trust at the dyadic level (Rowley et al. 2000).

Drawing upon the network perspective, we consider senior management involvement as a social component of IT governance, as the involvement of senior management enables shared behavior expectations, produces norms of appropriate IT behaviors (Lewis et al. 2003), and serves as part of the social control mechanism that governs employee behaviors (Rowley et al. 2000). Through the involvement of senior management in formal IT governance bodies, both structural and relational embeddedness are forged as formal authority is invested through an institutionalized network structure and dyadic relationships amongst network participants are enhanced. Through informal interactions in the process of considering and taking ITrelated decisions, personal relations are developed and relational embeddedness is enhanced.

Based on the discussion above, we anticipate the establishment of both structural and relational embeddedness of IT decisions at Healthcare and Pharma where formal steering committees were implemented. However, structural embeddedness is likely to be absent at Agriculture, where there seems to be only relational embeddedness built through informal personal interactions between the CIO and the operational/ functional executives.

When an organisation's senior managers are connected through either structural or relational embeddedness, a consistency in organisation-wide IT values is more likely to arise with IT-related strategies and tactics adjusted to coordinate the needs of individual units (Feldman 1981). The existence of this consistent enterprise perspective facilitates the communication and coordination of IT behaviours across organisation units. As a result, the efficiency of IT use is likely to be improved. Furthermore, the diffusion of expectations from senior managers enabled by structural and relational embeddedness implies the importance of IT and encourages extensive use of IT, leading to improved breadth of IT use as well. In addition, as enterprise norms are enabled by both structural embeddedness and relational embeddedness, norms that do exist are weakened if either structural or relational embeddedness is lacking (Jones et al. 1997; Kale et al. 2000), consequently challenging the consistent and active use of IT. Therefore, we suggest that IT performance will be most improved when both structural and relational embeddedness are present. Given that the formal involvement of senior management in governance procedures enriches both structural and relational embeddedness while informal involvement with the CIO enriches relational embeddedness alone, we anticipate that senior management involvement through formal steering committees will result in higher levels of efficiency and breadth of IT use than senior management involvement through informal personal relationships when only one of these is observed. Therefore, we recommend:

Recommendation 1: In order to enhance performance of IT use (as indicated by efficiency and breadth of IT use) in SMEs, senior management should be involved through joint formal and in formal IT governance interactions.

The evidence from this study also points to the fact that persons involved with the formal and/or informal IT governance interactions are important in explaining 
variation in an organisation's success in using IT. As shown in Table 4, Pharma outperformed HealthCare with both the efficiency of IT use and the breadth of current IT use, but not for the breadth of potential IT use - where, HealthCare outperformed Pharma. Such a pattern points to the importance of the composition of the IT steering committee. At HealthCare, it was the corporate executives that participated in the IT steering committee, whereas at Pharma it was the operational/functional executives who participated.

The CIO's IT-related decision interactions can involve corporate executives, operational executives, or both. Corporate executives are more knowledgeable about the corporate-level issues, but may lack deep knowledge of how IT can be used locally in improving organisational performance (Hadjimanoulis 2000). The involvement of corporate executives in IT decisions is critical to longer-term enterprise planning issue associated with IT, which requires substantial executive involvement in order to establish an appropriate alignment between IT directions and business directions (Segars and Grover 1998). In other words, with the involvement of corporate executives, conversations and explorations of where and how IT should be applied in the future are more likely to occur. We thus recommend that in order to improve the breadth of potential IT use, corporate-level executives should be involved in IT decision-making processes.

\section{Recommendation 2: In order to improve the breadth of potential IT use in SMEs, corporate executives should be involved in IT governance processes.}

On the other hand, operational executives have a greater understanding of local issues (IT-related and otherwise), but may lack a broad understanding of IT use from an enterprise-wide perspective. Given that operational managers are typically focused on meeting operational and budget performance targets, it is expected their primary interests with IT-related decisions will correspondingly focus on how to use IT in enhancing current operations and driving down costs (Tallon et al. 2000). Therefore, we expect the involvement of operational managers in IT governance processes to improve the breadth of current use of IT. Therefore, we recommend:

\section{Recommendation 3: In order to improve the breadth of current IT use in SMEs, operational executives should be involved in IT governance processes.}

\subsection{IT Governance Communication Practices}

Lastly, the data implied that heightened performance at Pharma regarding both efficiency in IT use and the breadth of current IT use may have been attributed to both the greater number - and nature (discussed below) - of communication channels used (Table 4). Effective IT governance communication practices are likely to prove influential in establishing an awareness of and familiarity with enterprise-wide IT governance policies, guidelines and practices across an organisation's management team. Communication practices that apply a variety of communication alternatives are likely to prove more effective than communication practices that apply only a few alternatives as targeted organisational members are more likely to access and, hence, be exposed to sent messages (Lengel and Daft 1988; Schmitz and Fulk 1991; 
Te'eni 2001). Therefore, when IT governance policies, guidelines and practices are communicated through more rather than fewer channels, organisational members are more likely to attend to these messages and, hence, be more aware of their organisation's IT-related strategies, actions and behaviors. Consequently, communicating IT policies, guidelines and procedures through more channels is more likely to improve the success which results from IT use:

Recommendation 4: In order to improve the performance of IT use (as indicated by efficiency and breadth of IT use) in SMEs, IT governance policies, guidelines and practices should be communicated through a number of channels.

On another note, it is interesting to observe that, while Agriculture used more channels to communicate IT policies, guidelines and practices than did HealthCare, Agriculture was found to exhibit lower performance than HealthCare regarding current and potential breadth of IT use. Agriculture did not utilize electronic channels, which were observed with both Healthcare (email) and Pharma (email and Intranet). Although we could not infer the direct link between communication channels and IT performance, we suspect that information accessibility enabled by electronic channels may have contributed to the difference in performance across three firms. We thus suggest that the greater accessibility (O'Reilly 1982) to information regarding IT governance policies, guidelines and practices afforded through electronic communication channels increased the likelihood that these policies, guidelines and practices would frame IT-related decisions and actions (Huber 1990) and improve organisational success with IT use. Therefore, we recommend:

Recommendation 5: In order to improve the performance of IT use (as indicated by efficiency and breadth of IT use) in SMEs, IT governance policies, guidelines and practices should be communicated through accessible channels.

\section{Discussion}

We began this paper with the question: How can SMEs optimize IT performance through governance practices? As expected, the examination of IT governance processes and IT use within three SMEs indicates that SMEs exhibit centralized governance structures, and this orientation toward centralized governance seemed most effective in promoting efficiency in IT use. Still, we also observed considerable variance in these three organisation's success in IT use. So, given their use of centralized IT governance structures, under which conditions will SMEs achieve both efficiency and breadth in IT use? Inferences from the patterns in data emerged from our analysis. Our recommendations focus on the effects on the manner in which senior executives in these organisations were involved with IT governance processes as well as their IT governance communication practices.

Regarding senior executive involvement in IT governance processes, we observed both the use of a formal IT steering committee and the organisational roles which involved senior executives to be influential in differentiating success in IT use. Consistent with previous research (e.g., McKeen and Guimaraes 1985; Ross et al. 
1996), the employment of formal IT steering committees was associated with higher success in IT use, rather than sole dependance on CIO-led interactions with senior executives,. Drawing upon the network perspective, we believe that IT steering committees enrich both structural and relational embeddedness, whereas CIO-led interactions enrich only relational embeddedness. Therefore, we suggest that it is through both the structural and relational embeddedness that social control mechanisms are enforced.

In addition to the presence of IT steering committees, it was observed that the identity of the individuals involved, formally or informally, with IT governance was also important. Weill and Ross (2005) suggest that steering committees largely comprising of enterprise-level participants tend to emphasize standardization and efficiency, whereas steering committees largely composed of operational managers tend to focus on improving operating performance. In addition to the intended focus, we built a direct connection between performance outcome and the composition of the committee. When corporate-level executives were involved, better performance was observed with the breadth of potential IT use; when operational/functional executives were involved, better performance was observed with breadth of current IT use. In other words, the involvement of corporate-level executives may be beneficial to IT performance in the long-run, whereas the involvement of operational executives may bring immediate benefits to IT performance. As none of the case sites were characterized by governance processes involving both corporate-level and operational/functional-level executives, we could not assess the value of such heterogeneous involvement practices - but we conjecture that such practices would prove helpful in organisational efforts to appropriate best value from IT investments.

Based on the observation that the involvement of corporate executives or operational executives leads to different outcomes in terms of IT performance, we wonder whether it is best to have a single steering committee with both corporate executives and operational executives, or two steering committees with one for corporate executives and one for operational executives. With one steering committee consisting of executives from both corporate and operational levels, it will be easier to connect the strategic and operational aspects of IT. Nevertheless, with a greater diversity in represented vested interests, it will likely be more difficult for participants to reach consensus and implement IT decisions.

On the other hand, establishing two separate committees - one focused more on strategic concerns and the other on operating concerns - will most likely result in more smoothly functioning governance bodies. Yet, by separating these two governance bodies the likelihood increases that disjunctures will surface in the policies and decisions that emanate. Both options have advantages and disadvantages, and existing literature lacks an exploration of resolution tactics. Given the important role that IT steering committees play in IT governance, we encourage future research that explores this issue within SMEs and within larger enterprises.

Regarding IT governance communication practices, prior research suggests that the dissemination of enterprise policies and guidelines is beneficial for achieving enterprise-wide understanding of IT expectations (Lind and Zmud 1995). We noted that the ways through which IT policies and practices are disseminated also mattered. The use of a greater number of channels may have contributed to greater success in IT use. More importantly, we observed that the use of electronic communication 
channels may prove especially effective in disseminating proscribed IT policies, guidelines and practices across an organisation's senior managers. As indicated from the three cases, Pharma utilized Intranet as a communication channel of IT policies and procedures and it outperformed the other two firms in terms of IT efficiency and breadth in current IT use. Given that an archival, electronic repository is most accessible and available, we wonder how beneficial it would be for organisations to electronically store important IT policies, guidelines and practices. Yet, given the limitation of our data, we cannot generate definite answers about this question, and we thus leave it open for future research.

\section{Conclusion}

This study has provided a view of IT governance practices in three SMEs, resulting in both an improved appreciation of the nature of IT governance practices in SMEs and the surfacing of key insights regarding effective governance practice that should enrich IT governance research in general. A qualitative and inductive study of three firms led us to recommend that in order for an organisation to improve overall IT performance, senior management should be jointly (both formally and informally) involved with IT decision-making processes and IT governance policies, guidelines and practices should be communicated to organisational members through more accessible communication channels. Furthermore, we also recommend that the involvement of corporate executives in IT governance processes will be beneficial for the breadth of potential IT use, whereas the involvement of operational executives will help the efficiency and breadth of current IT use.

Given that this study involves a small number of organisations, we acknowledge some of our observations may be due to the intrinsic nature of the organisations studied. For example, Agriculture is a non-profit organisation, and may not have sufficient resources to implement electronic media for disseminating IT policies and practices. The lack of formal steering committees at Agriculture may also deal with their business nature. On the other hand, HealthCare is relatively smaller than the other two firms, and may not need to disseminate IT policies and practices in multiple ways, resulting in a smaller number of communication channels used. Although we believe that the recommendations from this study is most salient to SMEs, we recommend that additional studies involving larger samples be conducted to validate the generalizability of our implications about IT governance in SMEs.

We sincerely hope that these ideas prove to be of interest and use to scholars interested in better understanding the structures and processes deployed by organisations to ensure that IT-related decisions are aligned with current operational goals and future strategies.

\section{References}

Bianchi, C.: Introducing SD modeling into planning and control systems to management SME's growth: a learning-oriented perspective. Systems Dynamics Review 18(3), 403-429 (2002) 
Blau, P.M., Schoenherr, R.A.: The Structure of Organisations. Basic Books, New York (1971)

Bourgeois, L.J., Eisenhardt, K.M.: Strategic Decision Processes in High Velocity Environments: Four Cases in the Mircrocomputer Industry. Management Science 34(7), 816-835 (1988)

Brown, A.E.: Framing the frameworks: A review of IT governance research. Communication of the Association for Information Systems 15, 696-712 (2005)

Brown, C.V.: Examining the Emergence of Hybrid IS Governance Solutions: Evidence from a Single Case Site. Information Systems Research 8(1), 69-94 (1997)

Brown, C.V., Magill, S.L.: Reconceptualizing the Context-Design Issue for the Information Systems Function. Organisation Science 9(2), 176-194 (1998)

Carlson, J.R., Zmud, R.W.: Channel Expansion Theory and the Experiential Nature of Media Richness Perceptions. Academy of Management Journal 42(2), 153-170 (1999)

Child, J.: Organisational Structure, Environment and Performance: The Role of Strategic Choice. Sociology 6(1), 1-22 (1972)

Cross, J., Earl, M.J., Sampler, J.L.: Transformation of the IT function at British Petroleum. MIS Quarterly 21(4), 401-424 (1997)

Daft, R.L., Lengel, R.H.: Organisational Information Requirements, Media Richness and Structural Design. Management Science 32(5), 554-571 (1986)

Doll, W.J.: Avenues for top management involvement in successful MIS development. MIS Quarterly 9(1), 17-35 (1985)

Doll, W.J., Torkzadeh, G.: The Relationship of MIS Steering Committeteo Size of Firm and Formalization of MIS Planning. Communications of the ACM 30(11), 7 (1987)

Dubé, L., Paré, G.: Rigor in Information Systems Positivist Case Research: Current Practices, Trends, and Recommendations. MIS Quarterly 27(4), 597-635 (2003)

Earl, M.J., Feeny, D.F.: Is Your CIO Adding Value. Sloan Management Review 35(3), 10 (1994)

Edmondson, A.C., Winslow, A.B., Bohmer, R.M., Pisano, G.P.: Learning How and Learning What: Effects of Tacit and Codified Knowledge on Performance Improvement Following Technology Adoption. Decision Science 34(2), 197-223 (2003)

Ein-Dor, P., Segev, E.: Organisational Context and MIS Structure: Some Empirical Evidence. MIS Quarterly 6(3), 55-68 (1982)

Eisenhardt, K.M.: Building Theories from Case Study Research. Academy of Management Review 14(4), 532-550 (1989)

Feldman, D.C.: The Multiple Socialization of Organisation Members. The Academy of Management Review 6(2), 309-318 (1981)

Foong, S.Y.: Effect of end user personal and systems attributes on computer based information system success in Malaysian SMEs. Journal of Small Business Management 37(3), 81-87 (1999)

Ghobadian, A., Gallear, D.N.: Total quality management in SMEs. Omega 24(1), 83-106 (1996)

Granovetter, M.: Economic Action and Social Structure: The Problem of Embeddedness. American Journal of Sociology 91, 481-510 (1985)

Granovetter, M.: Problems of explanation in economic sociology. In: Nohria, N., Eccles, R.G. (eds.) Networks and Organisations: Structure, Form, and Action, pp. 25-56. Harvard Business School Press, Boston (1992)

Gulati, R.: Alliances and networks. Strategic Management Journal 19(4), 293-317 (1998) 
Hadjimanoulis, A.: A resource-based view of innovativeness in small firms. Technology Analysis and Strategic Management 12(2), 263-281 (2000)

Hagmann, C., McCahon, C.: Strategic information systems and competitiveness: are firms ready for an IST-driven competitive challenge? Information \& Management 25, 183-192 (1993)

Hall, R.H.: Organisations, Structure and Process. Prentice-Hall, Englewood Cliffs (1972)

Hay, M., Kamshad, K.: Small firm growth: intentions, implementation and impediments. Business Strategy Review 5(3), 49-68 (1994)

Huber, G.P.: A Theory of the Effects of Advanced Information Technologies on Organisational Design, Intelligence, and Decision Making. Academy of Management Review 15(1), 47-71 (1990)

Jenkins, J.M., Santos, R.F.: Centralization vs. Decentralization of Data Processing Functions. In: Goldberg, R., Lorin, H. (eds.) The Economics of Information Processing, pp. 62-67. Whiley-Interscience, New York (1982)

Jones, C., Hesterly, W.S., Borgatti, S.P.: A General Theory of Network Governance: Exchange Conditions and Social Mechanisms. Academy of Management Review 22(4), 911-945 (1997)

Kale, P., Singh, H., Perlmutter, H.: Learning and Protection of Proprietary Assets in Strategic Alliances: Building Relational Capital. Strategic Management Journal 21, 217-237 (2000)

Kaplan, B., Maxwell, J.A.: Qualitative Research Methods for Evaluating Computer Information Systems. In: Anderson, J.G., Aydin, C.E. (eds.) Evaluating Health Care Information Systems: Methods and Applications, pp. 45-68. Sage, Thousand Oaks (1994)

Keasey, K., Watson, R.: Small firm management. Blackwell, Cambridge (1993)

Krishnan, M.S., Rai, A., Zmud, R.W.: Editorial Overview: The Digitally Enabled Extended Enterprise in a Global Economy. Information Systems Research 18(3), 233-236 (2007)

Lengel, R.H., Daft, R.L.: The selection of communication media as an executive skill. Academy of Management Executive 2, 225-232 (1988)

Levy, M., Powell, P.: Strategies for growth in SMEs. Elsevier, Burlington (2005)

Lewis, W., Agarwal, R., Sambamurthy, V.: Sources of Influence on Beliefs about Information Technology Use: An Empirical Study of Knowledge Workers. MIS Quarterly 27(4), 657$678(2003)$

Lind, M., Zmud, R.W.: Improving Interorganisational Effectiveness through Voice Mail Facilitation of Peer-to-Peer Relationships. Organisation Science 6(4), 445-461 (1995)

Lybaert, N.: The information use in a SME: its importance and some elements of influence. Small Business Economics 10, 171-191 (1998)

McKeen, J.D., Guimaraes, T.: Selecting MIS Projects by Steering Committee. Communications of the ACM (December 9, 1985)

Meyer, M.W.: Size and the Structure of Organisations: A Causal Model. American Sociological Review 37(4), 434-440 (1972)

O'Reilly, C.A.: Variations in Decision Makers' Use of Information Sources: The Impact of Quality and Accessibility of Information. Academy of Management Journal 25(4), 756-771 (1982)

Porter, M.E.: Competitive Advantage: Creating and Sustaining Superior Performance. Free Press, New York (1985)

Pugh, D.S., Hickson, D.J., Hinings, C.R., Turner, C.: Dimensions of Organisation Structure. Administrative Science Quarterly 13(1), 65-105 (1968)

Reich, B.H., Benbasat, I.: Factors That Influence the Social Dimension of Alignment between Business and Information Technology Objectives. MIS Quarterly 24(1), 81-113 (2000) 
Ross, J.W., Beath, C.M., Goodhue, D.L.: Develop Long-Term Competitiveness through IT Assets. Sloan Management Review 11 (Fall 1996)

Rowley, T., Behrens, D., Krackhardt, D.: Redundant governance structures: an analysis of structural and relational embeddedness in the steel and semiconductor industries. Strategic Management Journal 21(3), 369-386 (2000)

Rumelt, R.P.: How Much Does Industry Matter? Strategic Management Journal 12(3), 167-185 (1991)

Sambamurthy, V., Bharadwaj, A., Grover, V.: Shaping Agility through Digital Options: Reconceptualizing the Role of Information Technology in Contemporary Firms. MIS Quarterly 27(2), 237-263 (2003)

Sambamurthy, V., Zmud, R.W.: Managing IT for success: The empowering business partnership. Financial Executive Research Foundation, New Jersey (1992)

Sambamurthy, V., Zmud, R.W.: Arrangements for Information Technology Governance: A Theory of Multiple Contingencies. MIS Quarterly 23(2), 261-290 (1999)

Schmitz, J., Fulk, J.: Organisational colleagues, media richness, and electronic mail: A test of the social influence model of technology use. Communication of the Association for Information Systems 18, 487-523 (1991)

Segars, A.H., Grover, V.: Strategic Information Systems Planning Success: An Investigation of the Construct and Its Measurement. MIS Quarterly 22(2), 139-163 (1998)

Starbuck, W.H.: Handbook of Organisations. Rand-McNally, Chicago (1965)

Storey, D.: Understanding the Small Business Sector. Routledge, London (1994)

Storey, D., Sykes, N.: Uncertainty, innovation and management. In: Burns, P., Dewhurst, J. (eds.) Small Business and Entrepreneurship, pp. 73-93. Macmillan, London (1996)

Street, C.T., Meister, D.B.: Small Business Growth and Internal Transparency: The Role of Information Systems. MIS Quarterly 28(3), 473-506 (2004)

Tallon, P.P., Kraemer, K.L., Gurbaxani, V.: Executives' Perceptions of the Business Value of Information Technology: A Process-Oriented Approach. Journal of Management Information Systems 16(4), 145-173 (2000)

Te'eni, D.: Review: A Cognitive-Affective Model of Organisational Communication for Designing IT. MIS Quarterly 25(2), 251-312 (2001)

Thong, J.Y.L.: Resource constraints and information systems implementation in Singaporean small businesses. Omega 29(2), 143-156 (2001)

Thong, Y.L.: An Integrated Model of Information Systems Adoption in Small Businesses. Journal of Management Information Systems 15(4), 187-214 (1999)

Torkzadeh, G., Xia, W.: Managing Telecommunications by Steering Committee. MIS Quarterly 16(2), 13 (1992)

Uzzi, B.: The Sources and Consequences of Embeddedness for the Economic Performance of Organisations: The Network Effect. American Sociological Review 61(4), 674-698 (1996)

Vadapalli, A., Mone, M.A.: Information technology project outcomes: user participation structures and the impact of organisation behavior and human resource management issue. Journal of Engineering and Technology Management 17(2), 25 (2000)

Walker, G., Kogut, B., Shan, W.: Social Capital, Structural Holes and the Formation of an Industry Network. Organisation Science 8(2), 109-125 (1997)

Weill, P.: Don't just lead, govern: How top-performing firms govern IT. MIS Quarterly Executive 3(1), 1-17 (2004)

Weill, P., Ross, J.W.: IT Governance: How Top Performers Manage IT Decision Rights for Superior Results. Harvard Business School Press, Boston (2004) 
Weill, P., Ross, J.W.: A Matrixed Approach to Designing IT Governance. Sloan Management Review 46(2), 9 (2005)

Wilensky, H.: Hierarchical Control and Optimum Firm Size. Journal of Political Economy 75(2), 123-138 (1967)

Yin, R.: Case Study Research. Sage Publications, Beverly Hills (1984)

Zmud, R.W., Boynton, A.C., Jacobs, G.C.: The Information Economy: A New Perspective for Effective Information Systems Management. Data Base 18(1), 17-23 (1986) 